\title{
Effects of eri silkworm (Samia ricini) pupae inclusion in broiler diets on growth performances, health, carcass characteristics and meat quality
}

\author{
Penpicha Kongsup ${ }^{1}$, Somporn Lertjirakul ${ }^{2}$, Banthari Chotimanothum², \\ Pipatpong Chundang ${ }^{3}$, and Attawit Kovitvadhi ${ }^{3, *}$
}

\author{
* Corresponding Author: Attawit Kovitvadhi \\ Tel: +66-89-2022-677, Fax: +66-257-7538, \\ E-mail: fvetawk@ku.ac.th \\ Animal Health and Biomedical Science \\ Program, Faculty of Veterinary Medicine, \\ Kasetsart University, Bangkok 10900, \\ Thailand \\ ${ }^{2}$ The Queen Sirikit Department of Sericulture, \\ Ministry of Agriculture and Cooperatives, \\ Bangkok 10900, Thailand \\ ${ }^{3}$ Department of Physiology, Faculty of \\ Veterinary Medicine, Kasetsart University, \\ Bangkok 10900, Thailand \\ ORCID \\ Penpicha Kongsup \\ https://orcid.org/0000-0002-6088-4421 \\ Somporn Lertjirakul \\ https://orcid.org/0000-0001-8644-1066 \\ Banthari Chotimanothum \\ https://orcid.org/0000-0002-3529-2686 \\ Pipatpong Chundang \\ https://orcid.org/0000-0003-0159-0869 \\ Attawit Kovitvadhi \\ https://orcid.org/0000-0002-0769-5234
}

Submitted Jul 18, 2021; Revised Oct 27, 2021 Accepted Nov 15, 2021
Objective: The objective of this study was to determine the appropriate amount of eri silkworm pupae meal (Samia ricini) to add to the broiler diet.

Methods: Two hundred 1-day-old male chicks with initial weight at $50.03 \pm 0.56 \mathrm{~g} / \mathrm{chick}$ were divided into four groups (five replicates per group and ten chicks per replicate): a control group fed a corn-soybean diet and experimental groups supplemented with 5\%, $10 \%$, or $15 \%$ eri silkworm pupae meal. All experimental diets were isocaloric and isonitrogenous and formulated respecting nutrient requirements. Growth performances were collected during the experimental period and other parameters were collected at the end of experiment when broilers reached thirty-eight days old.

Results: A higher cold carcass weight and skin yellowness in the broilers fed $10 \%$ eri silkworm pupae meal compared with the other groups $(\mathrm{p}<0.05)$. Therefore, supplementation with $10 \%$ eri silkworm pupae meal is suggested for the broiler diet formulation because it did not cause any serious negative consequences on growth performance, health status, carcass characteristics and meat quality. However, the usage of eri silkworm pupae meal at $15 \%$ is not recommend because it led to negative outcomes

Conclusion: The addition of eri silkworm pupae at $10 \%$ can be used as an alternative protein sources for broiler chickens which provided benefits on cold carcass weight and skin yellowness without adverse effects.

Keywords: Broiler Chicken; Caecal Digestive Enzyme; Caecal pH; Color; Eri Silkworm

\section{INTRODUCTION}

The broiler chicken is an important livestock with high economic value that generates income for several countries and provides a secure protein source for the ever increasing world population. Broiler production increased around 18.5\% from 2015 to 2019. The feed is the major cost of animal production; the protein source represents the highest cost compared with the other raw materials. Generally, fishmeal and soybean meal are used as major protein sources for broiler feed. Fishmeal is an ideal protein raw material because it has a highly digestible and balanced amino acid profile [1-3]. However, fishmeal use in broiler diet formulations has gradually decreased because of several disadvantages regarding nutritional quality fluctuations, pathogen contamination and environmental impacts $[1,2]$. Therefore, soybean meal has become the major protein source for broilers instead of fishmeal [1-3]. However, soybean meal still has disadvantages because it lacks an essential amino acid (methionine), contains anti-nutritional factors, has low digestibility, leads to environmental deterioration from crop cultivation and can be contaminated with mycotoxins 
$[1,2]$. Given these issues, alternative raw protein materials that can be sustainably produced have been studied to replace these current protein sources.

Recently, insects have been of interest to researchers and farmers as sustainable alternative protein sources for broilers and other animal species. A short production cycle, a low investment cost, a small area required for insect production, the possibility that insects can consume by-products, high feed conversion ratio (FCR) and environmental friendliness are the advantages of using insects. Furthermore, using insects as a protein source can decrease the cost of broiler feed [1-3]. Extensive research has shown that several insect species are possible alternative protein sources in broilers: adult Mormon crickets (Anabrus simplex), black soldier fly larvae (Hermetia illucens), ground crickets (Gryllus testaceus), pallid emperor moth larvae (Cirina forda Westwood), Chinese grasshopper (Acrida cinerea), housefly larvae (Musca domestica) and yellow mealworm larvae (Tenebrio molitor) $[1,2,4-$ 7]. From most of these reports, the growth performance, health status, carcass weight and meat quality were not influenced by using insects in the broiler diet. Moreover, there are antimicrobial peptides in insects that influence the bacterial community and improve broiler health $[8,9]$. Therefore, insects could serve as alternative protein sources for broilers. There are several insect species that could be produced efficiently and used as protein sources. Therefore, the most suitable insect species, including silkworms, should be selected and studied.

The mulberry silkworm (Bombyx mori) has received the vast majority of research attention among silkworm species. Silk is the main valuable product produced by silkworms; their pupae are considered by-products. Mulberry silkworm pupae, muga silkworm pupae (Antheraea assamensis), tussore silkworm pupae (Antheraea mylitta) and silkworm caterpillars (Anaphe infracta) [6,7] are possible alternative protein sources in broiler nutrition. However, some silkworm pupae are consumed by humans and mulberry silkworms can only eat mulberry leaves [6]. Therefore, the cost of mulberry silkworms could be too high for use in broiler feed. Another interesting silkworm species, the eri silkworm (Samia ricini), can be produced in an environmentally sustainable manner. This species is resistant to hot climates and its highest production is in Asia and the Pacific region [6,10]. Interestingly, cassava leaves by-products from cassava production are used for eri silkworm feed; these leaves are low cost and support an upcycling economy. The pupal stage contains high quality nutrients and is rich in crude protein (CP), from $49.4 \%$ to $54.6 \%[6,11]$. The in vitro digestibility of CP based on simulations of the broiler digestive tract is similar to dehulled soybean meal [11]. Moreover, people prefers to consume mulberry silkworm rather than eri silkworms [10]. Given these factors, eri silkworms have the potential for use in broiler feed. However, the appropriate percentage to add in feed and the consequences on broilers are unknown. Therefore, this study evaluated the appropriate concentration of eri silkworm supplementation in broiler feed based on growth performances, health status, carcass characteristics and meat quality.

\section{MATERIALS AND METHODS}

\section{Care and use of animals}

This study was carried out following the standard guidelines approved by the Institutional Animal Care and Use Committee of Kasetsart University, Bangkok, Thailand (ACKU63VET-010).

\section{Amino acid profiles determination}

The amino acid composition was analysed using high performance liquid chromatography (HPLC) following the standard method of AOAC [12,13]. The ground, freeze dried eri silkworm pupae and dehulled soybean meal were hydrolysed with $6 \mathrm{~N} \mathrm{HCl}$ for 16 to $18 \mathrm{~h}$ at $110^{\circ} \mathrm{C}$. HPLC was performed using an Agilent 1290 Infinity II (UHPLC, Böblingen, Germany) with the following features: sample injection, multisample (G7167B); pump, flexible pump (G7104A); column: Agilent Poroshell HPH-C18 with guard column $\left(40^{\circ} \mathrm{C}\right.$ to maintain temperature for amino acids); detector: diode array detector (DAD; G7116B). Mobile phase A was borate buffer $\mathrm{pH} 8.2$ (filtered through a $0.45 \mu \mathrm{m}$ regenerated cellulose membrane) and mobile phase $\mathrm{B}$ was acetonitrile: methanol:water (45:45:10 v/v/v, all HPLC grade). For injection, $100 \mathrm{~mL}$ of mobile phase A was mixed with $0.4 \mathrm{~mL}$ of concentrated H3PO4. The flow rate was $200 \mu \mathrm{L} / \mathrm{min}$. Prior to injection, amino acids were derivatised with $y$-phthalaldehyde and 9-fluorenylmethyl chloroformate for primary amino acids and proline, respectively. Amino acid standard solutions was purchased from Agilent (Santa Clara, CA, USA).

\section{Insects, animals, husbandry, and diets}

Eri silkworm pupae were obtained from the Queen Sirikit Department of Sericulture (Bangkok, Thailand), where they had been boiled, subjected to silk reeling and frozen at $-20^{\circ} \mathrm{C}$ before arriving at the experimental site at the Faculty of Veterinary Medicine, Kasetsart University, Bangkok, Thailand. The eri silkworm pupae were dried at $60^{\circ} \mathrm{C}$ for $48 \mathrm{~h}$, ground to $1 \mathrm{~mm}$ and kept at $-20^{\circ} \mathrm{C}$ for use as an ingredient in experimental diets [11].

Two hundred 1-day-old male broiler chicks (Avian CP; Charoen Pokphand Foods PCL., Bangkok, Thailand) with initial weight at $50.03 \pm 0.56 \mathrm{~g} /$ chick were randomly assigned into four experimental group with five replicates per group and 10 birds per replicate. Chicks were vaccinated against Newcastle disease and infectious bronchitis by spraying in 
the hatchery. All chickens were placed in floor cages with rice hull as bedding inside a closed housing system under controlled a lighting programme ( $18 \mathrm{~h}$ light: $6 \mathrm{~h}$ dark) and able to access food and water ad libitum. The temperature of the experimental room was controlled at $34^{\circ} \mathrm{C}$ for 5 days and gradually decreased by $2^{\circ} \mathrm{C}$ per week to $26^{\circ} \mathrm{C}$, which was maintained until the end of the study at 38 days. The main protein raw material for the control group was soybean meal, whereas the eri silkworm pupae meal was used in the diet formulation at 5\% (5\%ERY), 10\% (10\%ERY) or $15 \%$ (15\%ERY) in the treatment groups. All starter (1 to 21 days old) and finisher (22 to 38 days old) mash diets were isocaloric and isonitrogenous and formulated respecting nutrient requirements. The ingredients and chemical composition of experimental diets was analysed in triplicate $[12,13]$ and the details are presented in Table 1 . Of note, the nitrogen-to-protein conversion factor was 4.76 for the eri silkworm pupae meal or 6.25 for the other ingredients [14].

\section{Growth performances, blood sample collection and slaughtering}

Live weight and feed intake (FI) were checked every 2 weeks throughout the experiment to calculate average daily weight gain (ADG), average daily feed intake (ADFI) and the FCR. In addition, the same observer recorded any morbidity and mortality daily. At the end of the experiments (38 days), serum was collected from the brachial wing vein $(n=5$ per replicate) to evaluate the levels of aspartate transaminase (AST) and alanine transaminase (ALT). Subsequently, at a commercial slaughterhouse all fattening broilers were weighed to obtain the slaughter weight (SW), shocked by electricity

Table 1. Ingredients and chemical composition of studied diets

\begin{tabular}{|c|c|c|c|c|c|c|c|c|}
\hline \multirow{3}{*}{ Items } & \multicolumn{4}{|c|}{ Starter diet (1 to $21 \mathrm{~d}$ ) } & \multicolumn{4}{|c|}{ Finisher diet (22 to $38 \mathrm{~d}$ ) } \\
\hline & \multirow{2}{*}{ Control } & \multicolumn{3}{|c|}{ Eri silkworm addition } & \multirow{2}{*}{ Control } & \multicolumn{3}{|c|}{ Eri silkworm addition } \\
\hline & & $5 \%$ & $10 \%$ & $15 \%$ & & $5 \%$ & $10 \%$ & $15 \%$ \\
\hline Corn & 50.8 & 54.2 & 57.6 & 61.1 & 62.8 & 66.1 & 69.8 & 73.1 \\
\hline Soybean meal $46.5 \%$ CP & 39.3 & 32.7 & 26.0 & 19.2 & 28.0 & 21.4 & 14.4 & 7.80 \\
\hline Eri silkworm powder & - & 5.00 & 10.0 & 15.0 & - & 5.00 & 10.0 & 15.0 \\
\hline Monodicalcium phosphate & 1.38 & 1.31 & 1.25 & 1.19 & 0.91 & 0.88 & 0.79 & 0.75 \\
\hline Limestone & 1.38 & 1.40 & 1.43 & 1.45 & 1.27 & 1.29 & 1.33 & 1.35 \\
\hline Salt & 0.24 & 0.24 & 0.24 & 0.24 & 0.19 & 0.19 & 0.19 & 0.19 \\
\hline Vitamin premix ${ }^{1)}$ & 0.16 & 0.16 & 0.16 & 0.16 & 0.16 & 0.16 & 0.16 & 0.16 \\
\hline Mineral premix ${ }^{2)}$ & 0.20 & 0.20 & 0.20 & 0.20 & 0.20 & 0.20 & 0.20 & 0.20 \\
\hline L-Lysine $\mathrm{HCl}$ & - & 0.10 & 0.20 & 0.32 & 0.17 & 0.28 & 0.41 & 0.53 \\
\hline \multicolumn{9}{|l|}{ Calculated composition (\% DM) } \\
\hline Crude protein ${ }^{3)}$ & 22.3 & 22.3 & 22.3 & 22.3 & 18.2 & 18.2 & 18.2 & 18.2 \\
\hline Metabolizable energy (kcal/kg) & 3,100 & 3,100 & 3,100 & 3,100 & 3,230 & 3,230 & 3,230 & 3,230 \\
\hline Methionine & 0.58 & 0.58 & 0.58 & 0.58 & 0.53 & 0.53 & 0.53 & 0.53 \\
\hline Methionine+cystein & 0.94 & 0.91 & 0.87 & 0.83 & 0.84 & 0.80 & 0.76 & 0.72 \\
\hline Calcium & 0.89 & 0.89 & 0.89 & 0.89 & 0.75 & 0.75 & 0.75 & 0.75 \\
\hline Available phosphorus & 0.45 & 0.45 & 0.45 & 0.45 & 0.38 & 0.38 & 0.38 & 0.38 \\
\hline \multicolumn{9}{|l|}{ Analyzed composition (\% DM) } \\
\hline Crude protein ${ }^{4}$ & 22.4 & 23.1 & 24.0 & 24.9 & 18.3 & 19.1 & 19.8 & 20.7 \\
\hline Ether extract & 8.37 & 7.21 & 6.05 & 4.87 & 8.28 & 7.15 & 5.93 & 4.80 \\
\hline
\end{tabular}

$\mathrm{CP}$, crude protein; DM, dry matter.

${ }^{1)}$ Vitamin premix (Feed specialties Co., Ltd; Pathumthani, Thailand) were supplied per kilogram of diets at 2,500,000 IU of vitamin A; 1,000,000 IU of vitamin $\mathrm{D}_{3} ; 7,000 \mathrm{lU}$ of vitamin $\mathrm{E} ; 700 \mathrm{mg}$ of vitamin $\mathrm{K} ; 400 \mathrm{mg}$ of vitamin $\mathrm{B}_{1} ; 800 \mathrm{mg}$ of vitamin $\mathrm{B}_{2} ; 400 \mathrm{mg}$ of vitamin $\mathrm{B}_{6} ; 4$ mg of vitamin $\mathrm{B}_{12} ; 30 \mathrm{mg}$ of biotin; 3,111 $\mathrm{mg}$ of Ca pantothenate acid; $100 \mathrm{mg}$ of folic acid; $15,000 \mathrm{mg}$ of vitamin C; $5,600 \mathrm{mg}$ of vitamin $\mathrm{B}_{3}$.

2) Mineral premix (Feed specialties Co., Ltd; Pathumthani, Thailand) were supplied per kilogram of diets at 10,500 mg of Zn, 10,920 mg of Fe; 9,960 mg of $\mathrm{Mn} ; 3,850 \mathrm{mg}$ of $\mathrm{Cu} ; 137 \mathrm{mg}$ of $\mathrm{l} ; 70 \mathrm{mg}$ of Se.

${ }^{3)}$ Nitrogen-to-protein conversion factor at 4.76 or 6.25 was used for the insect meal and other ingredients in feed formulation, respectively [21].

4) Nitrogen-to-protein conversion factor for analysed composition was used at $6.25[19,20]$. 
in a water bath and bled by cutting both jugular veins until broilers died [15].

\section{Carcass characteristics and meat quality analysis}

Carcass characteristics and meat quality analysis were adapted from the study by Kovitvadhi et al [15]. The hot carcass weight $(\mathrm{HCW})$ was obtained, and the feet, head, spleen and gastrointestinal tract were weighed after the slaughtering process. The caecal $\mathrm{pH}$ was immediately measured and the caecal material was collected and stored at $-20^{\circ} \mathrm{C}$ for further analysis on caecal digestive enzyme activities. The carcass was chilled at $4^{\circ} \mathrm{C}$ for $24 \mathrm{~h}$, after which time the cold carcass weight (CCW); dressing out percentage; and liver, breast, thigh, wing and meat/bone ratio were determined. The lightness and colour of the skin and pectoralis and gastrocnemius muscle at the same area for each carcass were evaluated with a chroma meter (CR-410; Konica Minolta, Tokyo, Japan). Breast muscle was collected in duplicate to determine meat $\mathrm{pH}$, drip loss after 24 and $48 \mathrm{~h}$ and thiobarbituric acid reactive substances after storage at $4^{\circ} \mathrm{C}$ for 7,14 , and 28 days. The dry matter (DM) and chemical composition of $\mathrm{CP}$, ether extract (EE) and crude ash of freeze-dried pectoralis and gastrocnemius muscles were determined in duplicate. The crude fat was also determined in the broiler liver $[12,13]$.

\section{Caecal digestive enzyme activities}

Caecal digestive enzyme activities were determined based on the study by Kovitvadhi et al [15] with adaptations. The caecal content was homogenised with phosphate-buffered saline (PBS, pH 7.0; 1:3 v/w), centrifuged at 18,000 g for 30 $\min$ at $4^{\circ} \mathrm{C}$ and the supernatant was removed and stored at $-80^{\circ} \mathrm{C}$ as crude enzyme extract (CTX) for further analysis. The caecal digestive enzyme activities were evaluated in duplicate.

For protease activity, $50 \mu \mathrm{L}$ of $2 \%$ casein in $0.2 \mathrm{M} \mathrm{NaOH}$, $200 \mu \mathrm{L}$ of $0.2 \mathrm{M} \mathrm{PBS}$ (pH 6.8) and $125 \mu \mathrm{L}$ of CTX was mixed and then incubated at $40^{\circ} \mathrm{C}$ for $15 \mathrm{~min}$. After the incubation, $5 \%$ trichloroacetic acid was added to terminate the enzymatic reaction, followed by centrifugation at 5,000 $\mathrm{g}$ for $20 \mathrm{~min}$ at $40^{\circ} \mathrm{C}$. Then, the supernatant was added to $350 \mu \mathrm{L}$ of $0.5 \mathrm{M}$ $\mathrm{NaOH}$ and $250 \mu \mathrm{L}$ of $5 \mathrm{M}$ Folin-Ciocalter reagent. The absorbance of the mixture was determined at $720 \mathrm{~nm}$. L-tyrosine was used as the reference [15].

To determine amylase activity, $25 \mu \mathrm{L}$ of $5 \%$ soluble starch in distilled water, $62.5 \mu \mathrm{L}$ of $0.2 \mathrm{M}$ PBS (pH 6.8), $37.5 \mu \mathrm{L}$ of $20 \mathrm{mM} \mathrm{NaOH}$ and $125 \mu \mathrm{L}$ of CTX were mixed together and then incubated at $40^{\circ} \mathrm{C}$ for $15 \mathrm{~min}$. After incubation, $250 \mu \mathrm{L}$ of 1\% 3,5-dinitrosalicylic acid (DNS) was added and the mixture was incubated in boiling water for $5 \mathrm{~min}$. Distilled water $(1.2 \mathrm{~mL})$ was added after the solution reached room temperature $\left(25^{\circ} \mathrm{C}\right)$. The absorbance was measured at 540 $\mathrm{nm}$, with maltose used as the standard [15].
To determine cellulase activity, $75 \mu \mathrm{L}$ of $1 \%$ carboxyl methyl cellulase, $425 \mu \mathrm{L}$ of $0.2 \mathrm{M}$ PBS (pH 6.8) and $50 \mu \mathrm{L}$ of CTX were mixed together and incubated at $40^{\circ} \mathrm{C}$ for $30 \mathrm{~min}$. Then, $300 \mu \mathrm{L}$ of $1 \%$ DNS was added and the solution was boiled in water for $10 \mathrm{~min}$. The absorbance was evaluated at $540 \mathrm{~nm}$, with glucose used as the standard [15].

To determine chitinase activity, $250 \mu \mathrm{L}$ chitin solution (10 mg of chitin), $250 \mu \mathrm{L}$ of $0.2 \mathrm{M}$ PBS (pH 6.5) and CTX were mixed and incubated at $40^{\circ} \mathrm{C}$ for $60 \mathrm{~min}$. After incubation, $300 \mu \mathrm{L}$ of $1 \%$ DNS was added and the solution was incubated in boiling water for $30 \mathrm{~min}$. The absorbance was measured at $560 \mathrm{~nm}$, with glucose used as the standard [16].

\section{Statistical analysis}

A completely randomised design was selected for this study. The control and experimental diets (fixed factors) were compared by one way analysis of variance with Duncan's multiple range test as the post hoc analysis. The effects of different levels of eri silkworm pupae meal were evaluated by using orthogonal polynomials for linear, quadratic and cubic effects. The normal distribution and homogeneity of variance were confirmed by the Shapiro-Wilk test and Levene's test, respectively. A difference was considered statistically significant at $\mathrm{p}<0.05$. All statistical analysis in the study was investigated by using $\mathrm{R}$ in RStudio ver.1.4.1103 with the Rcmdr package [17].

\section{RESULTS}

\section{Chemical composition and amino acid profiles in eri silkworm pupae}

One hundred grams of eri silkworm pupae on a DM basis ( $\mathrm{CP}=49.4 \%$ of $\mathrm{DM}$ using 4.76 as the nitrogen-protein conversion factor) contains aspartic acid, glutamic acid, serine, histidine, glycine, arginine, threonine, alanine, proline, cystine, tyrosine, valine, methionine, lysine, isoleucine, leucine and phenylalanine at $4.86,3.05,3.70,0.78,3.65,2.55,2.14$, $2.18,1.88$, not detected, $3.58,2.48,1.01,3.34,2.03,3.35$, and $2.60 \mathrm{~g}$, respectively. One-hundred grams of soybean meal on a DM basis ( $\mathrm{CP}=46.5 \%$ of $\mathrm{DM}$ using 6.25 as the nitrogenprotein conversion factor) contains $4.92,7.83,2.11,1.19,1.85$, $3.21,1.70,1.94,2.20,0.66,1.54,2.11,0.62,2.73,2.04,3.34$, and $2.24 \mathrm{~g}$, respectively

\section{Growth performances}

The productive performance of broilers fed different concentrations of eri silkworm pupae meal was presented in Table 2. There were no differences in the live weight and the ADG among the studied groups ( $p>0.05$ ). The highest ADFI and FCR at 1 to 14 days were observed in the 15\%ERY group $(\mathrm{p}<0.05)$. At 29 to 38 days, broilers fed 15\%ERY presented a lower ADFI compared with the control and 10\%ERY groups 
Table 2. Productive performances between broilers fed different addition of eri silkworm

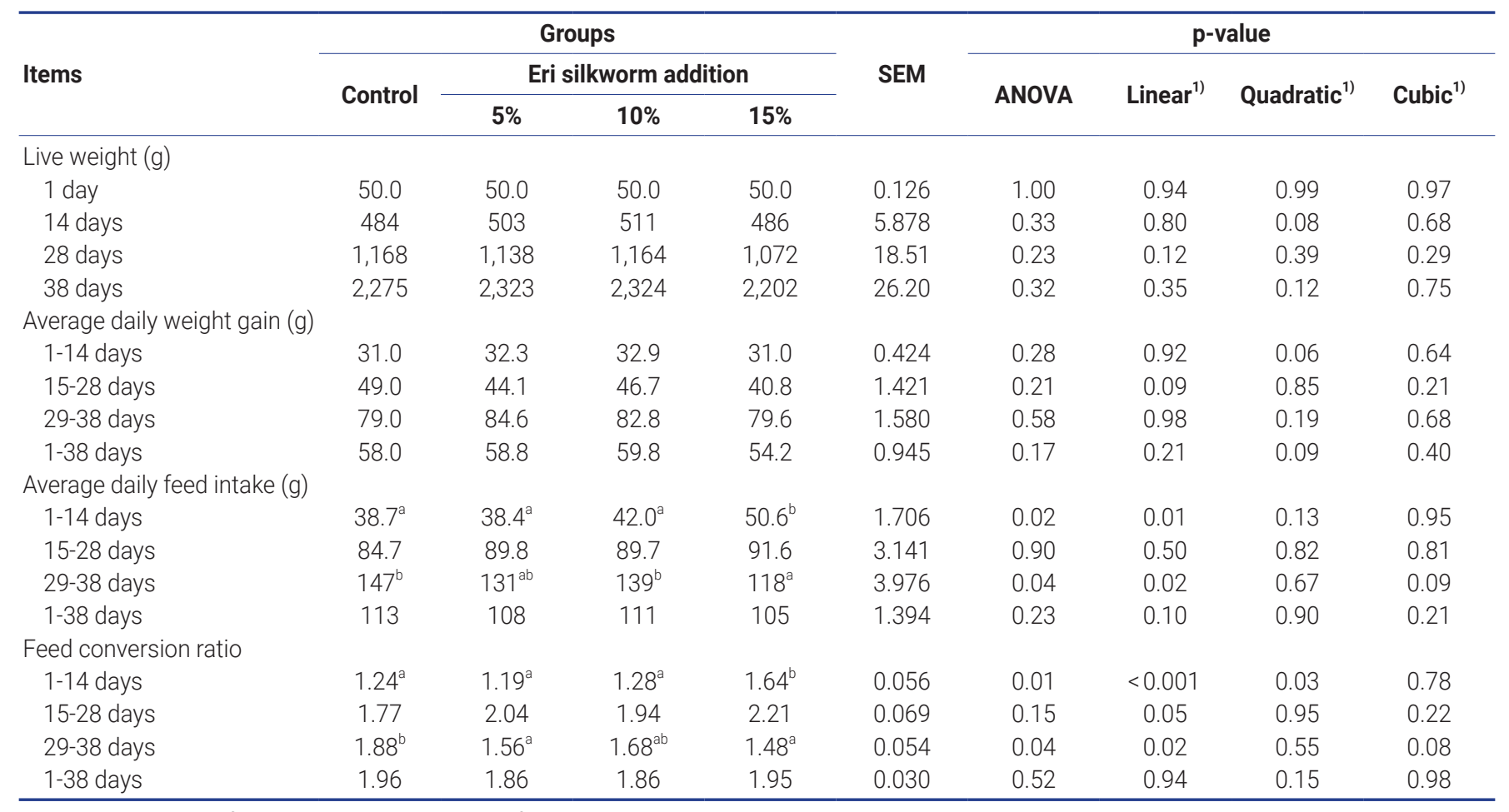

SEM, standard error of the mean; ANOVA, analysis of variance.

${ }^{1)}$ Orthogonal polynomial contrasts were calculated to determine the effect of dietary eri silkworm levels.

$a, b$ Means with different superscript differ at $p<0.05$.

$(\mathrm{p}<0.05)$. The FCR of 5\%ERY and 15\%ERY was lower than the control group $(\mathrm{p}<0.05)$. In addition, the ADFI and FCR did not differ among the study groups at 15 to 28 days and along the entire experiment ( $p>0.05)$. Based on the linear contrast results, supplementation with eri silkworm pupae meal at $10 \%$ increased the ADFI at 1 to 14 days and reduced the ADFI at 29 to 38 days $(\mathrm{p}<0.05)$. Consequently, the FCR at 1 to 14 and 29 to 38 days was increased and decreased, respectively $(\mathrm{p}<0.05)$.

The average final live weight and FCR were not difference between experimental groups ( $\mathrm{p}>0.05)$. There was no morbidity observed, but one and two broilers in the 5\%ERY and $15 \%$ ERY group, respectively, died.

\section{Liver enzymes, caecal pH, caecal digestive enzyme} activities and carcass characteristics

Table 3 presents the liver enzymes, caecal $\mathrm{pH}$, caecal digestive enzyme activities and carcass characteristics. The liver enzyme levels (AST and ALT) were not different among the groups ( $p>0.05$ ). In addition, broilers fed $15 \%$ ERY had more liver fat than the other groups $(\mathrm{p}<0.01)$. The control group had the lowest caecal $\mathrm{pH}$ at the end of the experiment $(38$ days); all broilers fed eri silkworm pupae meal presented a higher caecal $\mathrm{pH}$ than the control group $(\mathrm{p}<0.01)$. The caecal amylase activities in the control and 5\%ERY groups were higher than the other groups $(\mathrm{p}<0.001)$, whereas the control group had the highest caecal protease activity $(\mathrm{p}<0.001)$. The caecal cellulase and chitinase activities were not different among the experimental groups ( $\mathrm{p}>0.05$ ).

Interestingly, the group fed 10\%ERY had the highest CCW, whereas the group fed 15\%ERY had the lowest CCW ( $p<$ 0.05). In addition, the HCW and CCW presented a quadratic pattern in which the 10\%ERY supplementation showed the highest values; both measures decreased with 15\%ERY ( $\mathrm{p}<$ 0.05 ). The liver weight of broilers fed 15\%ERY was higher than other groups $(\mathrm{p}<0.001)$, whereas the control group had a higher gastrointestinal weight compared with the other groups $(\mathrm{p}<0.001)$. The $10 \% \mathrm{ERY}$ group had a lower spleen weight compared with the control and 5\%ERY groups ( $\mathrm{p}<$ 0.05 ) but $10 \%$ ERY group not difference with 15\%ERY. The SW and carcass characteristics regarding the HCW, feet, head, dressing out percentage, breast, thighs, wings and meat/bone ratio were not different among the groups ( $p>0.05)$.

\section{Skin color and meat quality}

Table 4 shows the skin colour and meat quality of the groups. There was greater redness, yellowness and chroma of the skin in the 10\%ERY and 15\%ERY groups compared with the control group $(\mathrm{p}<0.05)$; the lightness and hue angle did not differ among the groups ( $\mathrm{p}>0.05)$. The $15 \% \mathrm{ERY}$ group 
Table 3. Liver enzymes, liver fat, caecal pH, caecal digestive enzyme activities and carcass characteristics between broilers fed different addition of eri silkworm

\begin{tabular}{|c|c|c|c|c|c|c|c|c|c|}
\hline \multirow{3}{*}{ Items } & \multicolumn{4}{|c|}{ Groups } & \multirow{3}{*}{ SEM } & \multicolumn{4}{|c|}{ p-value } \\
\hline & \multirow{2}{*}{ Control } & \multicolumn{3}{|c|}{ Eri silkworm addition } & & \multirow{2}{*}{ ANOVA } & \multirow{2}{*}{ Linear ${ }^{1)}$} & \multirow{2}{*}{ Quadratic $^{1)}$} & \multirow{2}{*}{ Cubic $^{1}$} \\
\hline & & 5 & 10 & 15 & & & & & \\
\hline \multicolumn{10}{|l|}{ Liver enzymes } \\
\hline Aspartate transaminase (U/L) & 331 & 379 & 292 & 274 & 17.84 & 0.16 & 0.55 & 0.18 & 0.84 \\
\hline Alanine transaminase $(\mathrm{U} / \mathrm{dL})$ & 3.60 & 4.60 & 4.60 & 4.10 & 0.274 & 0.53 & 0.10 & 0.35 & 0.20 \\
\hline Liver fat (\% dry matter) & $18.3^{\mathrm{a}}$ & $15.6^{\mathrm{a}}$ & $22.9^{\mathrm{a}}$ & $40.8^{b}$ & 3.294 & 0.01 & 0.01 & 0.05 & 0.98 \\
\hline \multicolumn{10}{|l|}{ Caecal digestive enzyme activities } \\
\hline Amylase $(U)$ & $0.29^{\mathrm{bc}}$ & $0.32^{c}$ & $0.24^{\mathrm{b}}$ & $0.16^{\mathrm{a}}$ & 0.019 & $<0.001$ & $<0.001$ & 0.02 & 0.16 \\
\hline Protease (U) & $0.59^{b}$ & $0.47^{a}$ & $0.40^{\mathrm{a}}$ & $0.36^{\mathrm{a}}$ & 0.023 & $<0.001$ & $<0.001$ & 0.45 & 0.95 \\
\hline Cellulase (U) & 0.56 & 0.63 & 0.51 & 0.47 & 0.035 & 0.38 & 0.23 & 0.28 & 0.25 \\
\hline Chitinase $(U)$ & 0.16 & 0.14 & 0.13 & 0.12 & 0.007 & 0.25 & 0.05 & 0.83 & 0.81 \\
\hline \multicolumn{10}{|l|}{ Carcass characteristics } \\
\hline Head (\%HCW) & 3.75 & 3.75 & 3.67 & 3.63 & 0.037 & 0.57 & 0.18 & 0.81 & 0.70 \\
\hline Spleen (\%HCW) & $0.114^{\mathrm{bc}}$ & $0.121^{\mathrm{c}}$ & $0.099^{a}$ & $0.103^{\mathrm{ab}}$ & 0.002 & 0.01 & 0.01 & 0.75 & 0.01 \\
\hline Gastrointestinal tract (\%HCW) & $9.74^{\mathrm{b}}$ & $9.04^{\mathrm{a}}$ & $8.61^{\mathrm{a}}$ & $8.67^{a}$ & 0.088 & $<0.001$ & $<0.001$ & 0.02 & 0.78 \\
\hline Cold carcass weight (g) & $1,798^{\mathrm{ab}}$ & $1,826^{\mathrm{ab}}$ & $1,871^{\mathrm{b}}$ & $1,745^{\mathrm{a}}$ & 16.17 & 0.04 & 0.43 & 0.02 & 0.19 \\
\hline Dressing out (\%) & 79.0 & 79.0 & 80.4 & 79.2 & 0.248 & 0.11 & 0.42 & 0.20 & 0.06 \\
\hline Liver (\%CCW) & $2.42^{\mathrm{a}}$ & $2.49^{a}$ & $2.56^{\mathrm{a}}$ & $2.92^{b}$ & 0.041 & $<0.001$ & $<0.001$ & 0.06 & 0.39 \\
\hline Breast (\%CCW) & 21.6 & 21.9 & 22.8 & 23.3 & 0.271 & 0.09 & 0.01 & 0.81 & 0.71 \\
\hline Thighs (\%CCW) & 27.5 & 26.9 & 27.0 & 28.0 & 0.295 & 0.55 & 0.54 & 0.19 & 0.93 \\
\hline Wings (\%CCW) & 9.52 & 9.78 & 9.56 & 10.1 & 0.095 & 0.20 & 0.11 & 0.54 & 0.17 \\
\hline Meat/bone ratio & 4.39 & 5.05 & 4.70 & 5.01 & 0.121 & 0.23 & 0.18 & 0.47 & 0.12 \\
\hline
\end{tabular}

SEM, standard error of the mean; ANOVA, analysis of variance; HCW, hot carcass weight; CCW, cold carcass weight.

1) Orthogonal polynomial contrasts were calculated to determine the effect of dietary eri silkworm levels.

a,b Means with different superscript differ at $p<0.05$.

had lower lightness and greater redness, yellowness and hue angle in the breast (pectoralis muscle) compared with the other groups $(\mathrm{p}<0.001)$, whereas the chroma was not different among the groups $(p>0.05)$. The redness and yellowness of the skin and breast meat increased following a linear model as the amount of eri silkworm meal increased $(\mathrm{p}<0.001)$. There were no colour differences for the hindlimb muscle (gastrocnemius; $\mathrm{p}>0.05$ ) except higher lightness in the 5\%ERY compared with the control and 15\%ERY groups ( $\mathrm{p}<0.05)$. The 5\%ERY group had a higher drip loss percentage after storage for $24 \mathrm{~h}$ compared with the control and 15\%ERY groups $(\mathrm{p}<0.05)$. There were no differences found in meat $\mathrm{pH}$ after $24 \mathrm{~h}$, drip loss percentage after storage for $48 \mathrm{~h}$, thiobarbituric acid reactive substances (TBARS) and the chemical composition of the pectoralis and gastrocnemius muscles ( $\mathrm{p}>0.05)$.

\section{RESULTS AND DISCUSSION}

\section{Growth performances}

Growth performance can vary depending on the insect spe- cies used to supplement broiler feed $[2,18]$. There have been no reports of adverse effects on growth performance when replacing a low amount of fishmeal (2\% to $10 \%)$ in the broiler diet formulation with house fly larvae, silkworm caterpillar meal ( $A$. infracta), westwood larvae, yellow mealworm, grasshoppers or field crickets [2,4-7]. However, if too much insect meal is included in the diet, there can be deterioration of growth performance. In addition, the substitution of insect meal cannot deliver the same outcomes on growth performance as fishmeal [2,4-7].

Soybean meal has become a major protein source in broiler feed, replacing fishmeal in several countries. The partial replacement of soybean meal with black soldier fly larvae meal $10 \%$ to $20 \%$ in broiler feed [4] or $50 \%$ to $100 \%$ in layer feed $[2,7]$ did not affect productive performance. Furthermore, Mormon cricket meal was able to completely replace soybean meal without adverse effects. Moreover, the usage of house fly larvae [19] or yellow meal worm larvae [5,20] improved the FCR [21] compared with the control group fed using soybean meal as the protein source. Several studies have investigated the addition of silkworm pupae in broiler feed. 
Table 4. Skin color and meat quality between broilers fed different addition of eri silkworm

\begin{tabular}{|c|c|c|c|c|c|c|c|c|c|}
\hline \multirow{3}{*}{ Items } & \multicolumn{4}{|c|}{ Groups } & \multirow{3}{*}{ SEM } & \multicolumn{4}{|c|}{ p-value } \\
\hline & \multirow{2}{*}{ Control } & \multicolumn{3}{|c|}{ Eri silkworm addition } & & \multirow{2}{*}{ ANOVA } & \multirow{2}{*}{ Linear ${ }^{1)}$} & \multirow{2}{*}{ Quadratic $^{1)}$} & \multirow{2}{*}{ Cubic $^{1)}$} \\
\hline & & 5 & 10 & 15 & & & & & \\
\hline \multicolumn{10}{|l|}{ Skin color } \\
\hline Lightness $\left(L^{*}\right)$ & 63.6 & 61.4 & 63.2 & 61.3 & 0.417 & 0.09 & 0.16 & 0.85 & 0.04 \\
\hline Redness $\left(a^{\star}\right)$ & $13.0^{\mathrm{a}}$ & $14.4^{\mathrm{b}}$ & $14.7^{\mathrm{b}}$ & $14.9^{b}$ & 0.229 & 0.02 & $<0.001$ & 0.18 & 0.66 \\
\hline Yellowness $\left(b^{\star}\right)$ & $44.2^{\mathrm{a}}$ & $49.1^{\mathrm{ab}}$ & $50.4^{b}$ & $53.3^{b}$ & 1.004 & 0.01 & $<0.001$ & 0.59 & 0.55 \\
\hline Chroma $\left(C^{*}\right)$ & $46.2^{\mathrm{a}}$ & $51.2^{\mathrm{ab}}$ & $52.6^{b}$ & $55.3^{b}$ & 0.996 & 0.01 & 0.21 & 0.58 & 0.57 \\
\hline Hue $\left(H^{\star}\right)$ & 1.28 & 1.28 & 1.28 & 1.30 & 0.005 & 0.53 & $<0.001$ & 0.53 & 0.56 \\
\hline \multicolumn{10}{|c|}{ Meat color (Pectoralis muscle) } \\
\hline Lightness $\left(L^{\star}\right)$ & $58.1^{\mathrm{b}}$ & $59.0^{\mathrm{b}}$ & $58.1^{b}$ & $54.2^{\mathrm{a}}$ & 0.365 & $<0.001$ & $<0.001$ & $<0.001$ & 0.65 \\
\hline Redness $\left(a^{\star}\right)$ & $15.9^{a}$ & $15.7^{\mathrm{a}}$ & $16.4^{\mathrm{a}}$ & $17.8^{b}$ & 0.175 & $<0.001$ & $<0.001$ & 0.01 & 0.95 \\
\hline Yellowness (b*) & $28.1^{a}$ & $27.5^{\mathrm{a}}$ & $29.7^{a}$ & $32.9^{b}$ & 0.527 & $<0.001$ & $<0.001$ & 0.06 & 0.69 \\
\hline Chroma $\left(C^{*}\right)$ & 1.05 & 1.04 & 1.06 & 1.07 & 0.006 & 0.39 & 0.14 & 0.58 & 0.49 \\
\hline Hue $\left(H^{\star}\right)$ & $32.4^{\mathrm{a}}$ & $31.8^{\mathrm{a}}$ & $34.0^{\mathrm{a}}$ & $37.5^{b}$ & 0.510 & $<0.001$ & $<0.001$ & 0.03 & 0.71 \\
\hline \multicolumn{10}{|c|}{ Meat color (Gastrocnemius muscle) } \\
\hline Lightness $\left(L^{\star}\right)$ & $48.5^{\mathrm{a}}$ & $51.7^{\mathrm{b}}$ & $50.8^{\mathrm{ab}}$ & $48.4^{\mathrm{a}}$ & 0.479 & 0.03 & 0.75 & $<0.001$ & 0.55 \\
\hline Redness $\left(a^{\star}\right)$ & 19.6 & 18.9 & 18.3 & 20.1 & 0.270 & 0.09 & 0.71 & 0.02 & 0.33 \\
\hline Yellowness $\left(b^{\star}\right)$ & 27.1 & 23.7 & 25.8 & 29.5 & 0.870 & 0.12 & 0.24 & 0.04 & 0.63 \\
\hline Chroma $\left(C^{\star}\right)$ & 0.90 & 0.90 & 0.95 & 0.97 & 0.011 & 0.08 & 0.02 & 0.54 & 0.41 \\
\hline Hue $\left(H^{\star}\right)$ & 34.0 & 30.5 & 31.7 & 35.8 & 0.816 & 0.09 & 0.36 & 0.02 & 0.78 \\
\hline Meat pH after 24 hours & 5.73 & 5.85 & 5.79 & 5.80 & 0.030 & 0.60 & 0.58 & 0.36 & 0.36 \\
\hline Drip loss 24 hours (\%) & $8.88^{a}$ & $10.6^{b}$ & $9.87^{\mathrm{ab}}$ & $9.14^{\mathrm{a}}$ & 0.214 & 0.02 & 0.97 & $<0.001$ & 0.20 \\
\hline Drip loss 48 hours (\%) & 17.7 & 19.7 & 19.1 & 18.5 & 0.384 & 0.29 & 0.60 & 0.09 & 0.44 \\
\hline \multicolumn{10}{|c|}{ Thio-barbituric acid reactive substance after storage at $4^{\circ} \mathrm{C}(\mu \mathrm{g}$ malondialdehyde $/ \mathrm{mg})$ at } \\
\hline $7 d$ & 1.05 & 0.86 & 0.84 & 0.75 & 0.507 & 0.72 & 0.92 & 0.78 & 0.78 \\
\hline $14 \mathrm{~d}$ & 1.21 & 1.06 & 1.26 & 1.12 & 0.273 & 0.40 & 0.24 & 0.09 & 0.09 \\
\hline $28 d$ & 2.44 & 2.83 & 2.80 & 3.45 & 0.855 & 0.09 & 0.59 & 0.36 & 0.36 \\
\hline \multicolumn{10}{|c|}{ Chemical composition of Pectoralis muscle (\% fresh matter) } \\
\hline Moisture & 75.6 & 76.1 & 75.4 & 75.9 & 0.315 & 0.85 & 0.68 & 0.38 & 0.38 \\
\hline Crude ash & 1.98 & 1.92 & 2.58 & 3.07 & 0.240 & 0.26 & 0.77 & 0.67 & 0.67 \\
\hline Crude protein & 21.4 & 21.8 & 23.1 & 21.9 & 0.356 & 0.40 & 0.30 & 0.28 & 0.28 \\
\hline Ether extract & 1.86 & 1.28 & 1.34 & 1.39 & 0.258 & 0.66 & 0.55 & 0.73 & 0.73 \\
\hline \multicolumn{10}{|c|}{ Chemical composition of Gastrocnemius muscle (\% fresh matter) } \\
\hline Moisture & 76.6 & 76.3 & 76.8 & 76.7 & 0.237 & 0.91 & 0.77 & 0.49 & 0.49 \\
\hline Crude ash & 1.03 & 1.23 & 1.08 & 1.32 & 0.060 & 0.32 & 0.40 & 0.18 & 0.18 \\
\hline Crude protein & 20.5 & 21.6 & 19.1 & 19.9 & 0.431 & 0.20 & 0.19 & 0.07 & 0.07 \\
\hline Ether extract & 2.64 & 3.12 & 3.32 & 3.01 & 0.220 & 0.79 & 0.69 & 0.91 & 0.91 \\
\hline
\end{tabular}

SEM, standard error of the mean; ANOVA, analysis of variance

1) Orthogonal polynomial contrasts were calculated to determine the effect of dietary eri silkworm levels.

a,b Means with different superscript differ at $p<0.05$.

The usage of mulberry, muga and tussore silkworm pupae to replace fishmeal at $50 \%$ or $5 \%$ to $10 \%$ in feed formulation did not cause adverse effects on productive performance [6]. In addition, supplementation of around $5 \%$ of the feed formulation with silkworm pupae improved the FCR and reduced the production cost. In the same way as other insects, substitution at $15 \%$ or $20 \%$ in the feed formulation promoted negative consequences on productive performance $[1,2$, $7,21]$. The results in this study are consistent with these findings, especially considering the HCW and CCW. Therefore, the appropriate level of addition is an important consideration regarding which insect species to use in feed.

The growth performance of broilers are influenced not only by level of insect meal addition but also the chemical composition and digestibility of the meal [2,4-6]. The diets used in this study were isocaloric and isonitrogenous. However, the calculated $\mathrm{CP}$ was lower than the analysed $\mathrm{CP}$ because of the different nitrogen-protein conversion factor used. Insects have chitin, which contains non-protein nitrogen molecules; therefore, the amount of CP should be multiplied by a lower nitrogen-protein conversion factor [14]. Hence, a nitrogen-protein conversion factor of 4.76 was used for the eri silkworm pupae meal, whereas a value of 6.25 was used for the other raw materials. In other studies, the analysed CP was measured in complete mixed diets using a nitrogen-protein conversion factor of 6.25. Based on this formulation, the 
differences we noted regarding productive performance could be due to the different amino acid profiles and digestibility between the soybean meal and eri silkworm pupae meal and not due to a different CP content.

Similarly to mulberry silkworm pupae, the eri silkworm pupae had lower cysteine compared with soybean meal [6]. In a previous study, broilers fed by partly defatted black soldier fly larvae, which has insufficient cysteine, induced a cysteine-sparing effect due to a lack of methionine and led to a deterioration of growth performance and FI [22]. Fortunately, maggot meal, silkworm pupae, mealworms and eri silkworms contain more methionine than soybean meal [19]. Therefore, the severe negative outcomes of cysteine deficiency were not observed in this study. Moreover, ecdysteroid, an insect hormone for metamorphosis that has growth-stimulating properties, has been found in silkworm pupae [6]. This could be another reason why the FCR was improved in the 5\%ERY and 10\%ERY groups, whereas $15 \%$ eri silkworm pupae meal could represent too much supplementation considering the lack of cysteine and/or methionine. Additional investigation is required to confirm this hypothesis.

Crude fiber, ADF and chitin $[1,11]$ in insect meal are negatively correlated with protein digestibility. Therefore, supplementing broiler feed with insects that contain high levels of these chemical components could lead to lower protein digestion and, consequently, poor performance. Based on in vitro digestibility on crude protein from broiler crude enzyme extract, Bombay locust (Patanga succincta), housefly larvae, lesser wax moth larvae (Achroia grisella) and yellow mealworm were similar to fishmeal and higher than dehulled soybean meal, whereas mulberry and eri silkworm were similar to dehulled soybean meal [6]. Moreover, the digestibility of DM and nutrients were not different between broilers fed a diet with mulberry silkworm pupae or soybean meal. This result could indicate that silkworm pupae have the potential to replace soybean meal. In addition, the digestibility can be improved by enzyme addition or pre-fermentation [7].

\section{Skin color, carcass characteristics and meat quality}

There are very few studies available in the literature on the skin colour of broilers fed insect meal. The use of housefly maggot meal at $10 \%$ or $20 \%$ in broiler feed did not change the breast meat colour [2]. However, the inclusion of yellow mealworms [20] or black soldier fly larvae [23] led to more lightness, redness and yellowness of breast meat. We also found increased yellowness with the inclusion of eri silkworm pupae meal. Generally, an increase in yellowness is due to pigments in the diet. On the one hand, pigments were observed in most of insects and several classes of pigments are involved with insect colouration. Melanins produce shades from black to reddish-brown, and pterins, ommochromes and carotenoids contribute to red, orange, and yellow colours [24]. Therefore, the increased yellowness in meat and skin could be due to the pigments inside eri silkworm pupae. In addition, insect meals contain a high proportion of mediumchain fatty acids, mainly lauric acid, whereas polyunsaturated fatty acids are mainly found in palm oil, which was used in control diet. Lipid peroxidation is a major concern regarding product quality and safety. TBARS was not different among the studied groups, and thus the inclusion of eri silkworm pupae meal did not cause lipid peroxidation. The fatty acid profiles from diets was similar in meat [23]; therefore, the increased yellowness could due to the insect oil deposited in the broiler's meat and skin. This change could promote better consumer perception.

Carcass traits of broilers were not changed by supplementing feed with housefly larvae or yellow mealworms [2]. By contrast, the final weight of broilers showed a trend for an increase in the 10\%ERY group compared with the other groups, which led to a significant difference in the CCW. On the one hand, broilers fed by supplementation with grasshoppers [24], black soldier fly larvae [23], African palm weevil larvae (Rhynchophorus phoenicis). In addition, the breast muscle weight was increased by supplementation of oil from black soldier fly larvae [23].

\section{Liver enzymes, liver fat, caecal $\mathrm{pH}$ and caecal digestive enzyme activities}

The liver weight was increased following 15\%ERY supplementation; this change was likely due to greater liver function or deposited fat. The levels of enzymes that indicate liver damage, AST and ALT, were not increased in the experimental groups; therefore the supplementation of eri silkworm pupae meal did not lead to hepatic damage. In another study, lipid accumulation in the liver of broilers retarded the production of methionine but did not negatively affect the liver [24]. We speculate that the different fatty acid profiles between palm oil and insect oil could be the cause of this outcome. Based on our results, the usage of 15\%ERY longer than 38 days might induce hepatic damage. The damages of hepatic function has been implicated to reduce growth performance and threaten the health of birds, causing economic losses to the poultry industry [25]. Therefore, long-term usage in layers and parent stocks should be carefully considered.

The microbial community correlates to the health status in broilers; this factor can be roughly represented by the caecal $\mathrm{pH}$ and digestive enzyme activities. The increase in shortchain fatty acids after microbial fermentation reduces the $\mathrm{pH}$ [2]. The control group had a lower caecal $\mathrm{pH}$ compared with the experimental groups. The elevated $\mathrm{pH}$ is caused by more ammonia, leading to pathogen growth and risk for morbidity [2]. However, the caecal pH of the experimental groups was still in the normal range [2] and none of groups 
showed morbidity. Therefore, the supplementation did not negatively affect the health status. The differences in amylase and protease activities among the groups indicate modifications to the microbial community. Chitinase is excreted from microbes inside the chicken caecum [2,7]. We expected that the chitinase activity would increase as the level of eri silkworm pupae meal in the feed increased. However, the chitinase activity was not different among the studied groups. Hence, the tested levels of eri silkworm pupae meal did not affect the bacteria that produced chitinase. Therefore, the microbial community inside commercial broilers did not support the increase of chitin level from insects. The appropriate level of insect meals supplementation must be the important consideration point to prevent negative outcomes on lower digestibility and increase FCR. More in-depth studies on the microbial community based on genetic techniques could be performed to confirm whether eri silkworm pupae meal benefits or harms the caecal microbial community.

\section{CONCLUSION}

This study aimed to determine the appropriate level of eri silkworm pupae meal to include in broiler feed. Based on the results, the addition of $10 \%$ eri silkworm pupae meal had a CP similar to dehulled soybean meal (26\%). Compared with the control group, these broilers presented a higher final weight, a lower FCR and a higher CCW. Interestingly, the yellowness of the skin increased in the 10\%ERY and $15 \%$ ERY groups compared with the control group $(\mathrm{p}<$ 0.01). All broilers fed diets containing eri silkworm pupae meal presented a higher caecal $\mathrm{pH}$ compared with the control group $(p<0.01)$. There was a trend for reduced caecal amylase and protease activities compared with the control group. The addition of eri silkworm pupae meal in the broiler diets did not promote serious negative consequences on other growth performance parameters, liver enzymes, carcass traits and meat quality. Based on the study results, we suggest adding $10 \%$ eri silkworm pupae meal to broiler feed. The usage of $15 \%$ eri silkworm pupae meal is not suggested because it caused negative outcomes: lower final weight, higher FCR, lower CCW and higher liver weight. Additional studies on cost effectiveness, the fatty acid profile in meat and the microbial community could be of interest to confirm the usage of eri silkworm pupae as an alternative protein source for broilers.

\section{CONFLICT OF INTEREST}

We certify that there is no conflict of interest with any financial organization regarding the material discussed in the manuscript.

\section{ACKNOWLEDGMENTS}

This research study was funded by National Research Council of Thailand (NRCT). This work was partially supported by the Faculty of Veterinary Medicine, Kasetsart University, Bangkok, Thailand. The authors would like to humbly thank to Charoen Pokphand Foods PCL. (Bangkok, Thailand) and Feed Specialties Co., Ltd (Pathumthani, Thailand) to provide broiler chicks and raw materials to perform diets, respectively. The authors would like to thanks to Dr. Sathita Areerat and Ms. Nichaphon Pliantiangtam for technical assistance on animal husbandry and sample collection.

\section{REFERENCES}

1. Gasco L, Biasato I, Dabbou S, Schiavone A, Gai F. Animals fed insect-based diets: State-of-the-art on digestibility, performance and product quality. Animals 2019;9:170. https:// doi.org/10.3390/ani9040170

2. Chodová D, Tùmová E. Insects in chicken nutrition. A review. Agron Res 2020;18:376-92. https://doi.org/10.15159/AR. 20.003

3. Khan S, Khan RU, Alam W, Sultan A. Evaluating the nutritive profile of three insect meals and their effects to replace soybean in broiler diet. J Anim Physiol Anim Nutr 2018;102:e662-8. https://doi.org/10.1111/jpn.12809

4. Barragan-Fonseca KB, Dicke M, Van Loon JJ. Nutritional value of the black soldier fly (Hermetia illucens L.) and its suitability as animal feed-a review. J Insects Food Feed 2017;3:105-20. https://doi.org/10.3920/JIFF2016.0055

5. Hong J, Han T, Kim YY. Mealworm (Tenebrio molitor Larvae) as an alternative protein source for monogastric animal: a review. Animals 2020;10:2068. https://doi.org/10.3390/ani 10112068

6. Jozefiak A, Engberg RM. Insect proteins as a potential source of antimicrobial peptides in livestock production. A review. J Anim Feed Sci 2017;26:87-99. https://doi.org/10.22358/jafs/ 69998/2017

7. Józefiak A, Benzertiha A, Kierończyk B, Łukomska A, Wesołowska I, Rawski M. Improvement of cecal commensal microbiome following the insect additive into chicken diet. Animals 2020;10:577. https://doi.org/10.3390/ani10040577

8. Sheikh IU, Banday MT, Baba IA, et al. Utilization of silkworm pupae meal as an alternative source of protein in the diet of livestock and poultry: a review. J Entomol Zool Stud 2018;6: 1010-6.

9. Khan SH. Recent advances in role of insects as alternative protein source in poultry nutrition. J Appl Anim Res 2018; 46:1144-57. https://doi.org/10.1080/09712119.2018.1474743

10. Wongsorn D, Sirimungkararat S, Saksirirat W. Improvement of eri silkworm (Samia ricini D.) tolerance to high temperature and low humidity conditions by discontinuous regime. 
Songklanakarin J Sci Technol 2015;37:401-8.

11. Kovitvadhi A, Chundang P, Pliantiangtam N, et al. Screening of in vitro nutrient digestibility coefficients of selected insect meals in broiler chickens, black-meat chickens and quails. J Anim Physiol Anim Nutr (Berl) 2020;105:305-15. https:// doi.org/10.1111/jpn.13451

12.Latimer GW. Official methods of analysis. Washington, DC, USA: AOAC International; 1990.

13. Horowitz W, Latimer GW. Official methods of analysis. Gaithersburg, MD, USA: AOAC International; 2006.

14.Janssen RH, Vincken J, Van den Broek LAM, Fogliano V, Lakemond CMM. Nitrogen-to-protein conversion factors for three edible insects: Tenebrio molitor, Alphitobius diaperinus, and Hermetia illucens. J Agric Food Chem 2017;65:2275-8. https://doi.org/10.1021/acs.jafc.7b00471

15. Kovitvadhi A, Chundang P, Thongprajukaew K, Tirawattanawanich C. Effects of different ambient temperatures on growth performances, digestibility, carcass traits and meat chemical components in fattening rabbits. J Agric 2019;35: 495-502.

16.Zhou G, Li LJ, Shi QS, Ouyang YS, Chen YB, Hu WF. Effects of nutritional and environmental conditions on planktonic growth and biofilm formation of Citrobacter werkmanii BF-6. J Microbiol Biotechnol 2013;23:1673-82. https://doi. org/10.4014/jmb1307.07041

17.R-statistic Core Team. C. R: A language and environment for statistical computing: c2021 [cited 2021 Mar 22]. Available from: http://www.R-project.org/

18.Sedgh-Gooya S, Torki M, Darbemamieh M, Khamisabadi H, Karimi Torshizi MA, Abdolmohamadi A. Yellow mealworm, Tenebrio molitor (Col: Tenebrionidae), larvae powder as dietary protein sources for broiler chickens: Effects on growth performance, carcass traits, selected intestinal microbiota and blood parameters. J Anim Physiol Anim Nutr (Berl) 2021; 105:119-28. https://doi.org/10.1111/jpn.13434

19. Brede A, Wecke C, Liebert F. Does the optimal dietary methionine to cysteine ratio in diets for growing chickens respond to high inclusion rates of insect meal from Hermetia illucens. Animals 2018;8:187. https://doi.org/10.3390/ani8110187

20. Maurer V, Holinger M, Amsler Z, et al. Replacement of soybean cake by Hermetia illucens meal in diets for layers. J Insects Food Feed 2016;2:83-90. https://doi.org/10.3920/ JIFF2015.0071

21. Bovera F, Piccolo G, Gasco L, et al. Yellow mealworm larvae (Tenebrio molitor, L.) as a possible alternative to soybean meal in broiler diets. Br Poult Sci 2015;56:569-75. https:// doi.org/10.1080/00071668.2015.1080815

22.Zegeye DM. Nutritional evaluation of insect's pupae-larvae and its utilization in poultry compound feed. Open Agric J 2020;14:1-8.

23. Badejo O, Skaldina O, Gilev A, Sorvari J. Benefits of insect colours: a review from social insect studies. Oecologia 2020; 194:27-40. https://doi.org/10.1007/s00442-020-04738-1

24. Jariyahatthakij P, Chomtee B, Poeikhampha T, Loongyai W, Bunchasak C. Effects of adding methionine in low-protein diet and subsequently fed low-energy diet on productive performance, blood chemical profile, and lipid metabolismrelated gene expression of broiler chickens. Poult Sci 2018; 97:2021-33. https://doi.org/10.3382/ps/pey034

25.Zaefarian F, Mohammad RA, Aaron C, Velmurugu R. Avian liver: the forgotten organ. Animals 2019;9:63. https://doi.org/ 10.3390/ani9020063 